\title{
Effects of shear and cooling rates on the crystallization behavior of cocoa butter
}

\section{Kakao yağının kristalleşme davranışı üzerinde kayma hızı ve soğutma hızının etkileri}

\author{
Gülten ŞEKEROĞLU1* iD, Ahmet KAYA \\ ${ }^{1}$ University of Gaziantep, Vocational School of Technical Sciences, Food Processing Department, 27310 Gaziantep, Turkey \\ ${ }^{2}$ University of Gaziantep, Engineering Faculty, Food Engineering Department, 27310 Gaziantep, Turkey \\ ${ }^{1}$ https://orcid.org/0000-0002-5499-1028; ${ }^{2}$ https://orcid.org/0000-0001-6960-3780
}

\section{To cite this article:}

Şekeroğlu, G. \& Kaya, A. (2021). Effects of shear and cooling rates on the crystallization behavior of cocoa butter. Harran Tarım ve Gıda Bilimleri Dergisi, 25(2):120-130.

DOI: $10.29050 /$ harranziraat.843455

*Address for Correspondence: Gülten ŞEKEROĞLU

e-mail:

sekeroglu@gantep.edu.tr

Received Date:

19.12.2020

Accepted Date:

26.05.2021

(C) Copyright 2018 by Harran University Faculty of Agriculture. Available on-line at www.dergipark.gov.tr/harranziraat

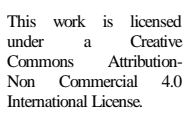

\section{ABSTRACT}

The purpose of this study was to determine the effects of shear and cooling-heating rates on the rheological behavior of cocoa butter. Three different shear rates $\left(25,50\right.$ and $\left.100 \mathrm{~s}^{-1}\right)$ and two different cooling rates $\left(1\right.$ and $\left.10^{\circ} \mathrm{C} \cdot \mathrm{min}^{-1}\right)$ were applied for crystallization of cocoa butter at 20,22 and $24^{\circ} \mathrm{C}$. Also, effects of shear and heating-cooling rates were monitored during the cooling and heating cycle between $70-20^{\circ} \mathrm{C}$. When the cooling rate was $1^{\circ} \mathrm{C} \cdot \mathrm{min}^{-1}$, viscosity reached the highest value of $0.6 \mathrm{~Pa}$.s with a shear rate of $25 \mathrm{~s}^{-1}$. A rapid rate of cooling generally led to nucleation at a lower temperature compared to slow cooling. It was observed that crystallization of Form $V$ was improved by shear and induction time of crystallization decreased as the rate of shear increased. The longest induction period was obtained at $24^{\circ} \mathrm{C}$. Effect of cooling rate was more significant at low temperatures $(P<0.05)$. It was also concluded that the crystallization behavior of cocoa butter was dependent on both shear and cooling rates under isothermal conditions.

Key Words: Chocolate, Cocoa butter, Crystallization, Rheological behavior, Viscosity

ÖZ

Bu çalışmanın amacı kakao yağının akışkanlık özellikleri üzerinde soğutma-ısıtma hızının ve kayma hızının etkisini belirlemektir. Kakao yağının 20,22 ve $24^{\circ} \mathrm{C}$ de kristallendirilmesinde üç farklı kayma hızı $\left(25,50\right.$ ve $\left.100 \mathrm{~s}^{-1}\right)$ ve iki farklı soğutma hızı $\left(1\right.$ ve $10{ }^{\circ} \mathrm{C}$.dak $\left.{ }^{-1}\right)$ uygulanmıştır. Ayrıca, $70-20^{\circ} \mathrm{C}$ aralığında uygulanan soğutma ve ısıtma evrelerinde, kayma hızı ve ısıtmasoğutma hızının etkisi takip edilmiştir. Ulaşılan en yüksek viskozite değeri 0.6 Pa.s olup, 1 ${ }^{\circ} \mathrm{C}$.dak ${ }^{-1}$ soğutma hızı ve $25 \mathrm{~s}^{-1}$ kayma hızı uygulandığında ölçülmüştür. Hızlı soğutma, yavaş soğutmaya göre genellikle daha düşük sıcaklıklarda çekirdeklenme oluşuma yol açmıştır. Kayma hızındaki artışla beraber, Form $\mathrm{V}$ tipindeki kristalleşme artarken, kristalleşme indüksiyon süresinin de azaldığı gözlenmiştir. En uzun indüklenme süresi $24^{\circ} \mathrm{C}$ de elde edilmiştir. Soğutma hızının etkisinin, düşük sıcaklıklarda daha önemli olduğu tespit edilmiştir ( $P$ < 0.05). Ayrıca, kakao yağının izotermal koşullardaki kristalleşme davranışında hem kayma hızının hem de soğutma hızının etkili olduğu sonucuna varıımıştır.

Anahtar Kelimeler: Çikolata, Kakao yağı, Kristalleşme, Reolojik davranış, Viskozite

\section{Introduction}

Chocolate is a complex rheological system in which sugar and non-fat cocoa particles coated with cocoa butter. Crystallization is often critical step in chocolate production and poor crystallization results fat bloom in chocolate products (Afoakwa et al., 2007; Schenk and Peschar, 2004; Beckett, 1999). Cocoa butter is a pale yellow natural fat, obtained from cocoa nib 
by hydraulic or expeller pressing (Yıldırım et al., 2016). Cocoa butter makes up about one-third of the chocolate composition, and its crystalline state governs the physical and thermal properties of the chocolate (Padar et al., 2009).

The solidification properties of cocoa butter are important phenomena that influence its functional properties in chocolate (Campos and Marangoni, 2014). The expected mouth feel of chocolate depends mainly on the composition of cocoa butter which means melting point of fractions in cocoa butter (Beckett, 2006; ToroVazquez et al., 2004). Cocoa butter is a mixture of triacylglycerol (TAG) and other compounds (Foubert et al., 2006). Although more than 25 different TAG have been identified in cocoa butter, approximately $85 \%$ of composition consists of mainly three TAG; POP, POS and SOS where stearic $(S)$, palmitic $(P)$ and oleic $(O)$ acids are attached to the glycerol bone (Le Révérend, et al., 2009; Perez-Martinez et al., 2007; Lipp and Anklam, 1998a; Loisel et al., 1998; Koyano et al., 1990). The studies show that they were the most important ones and the crystallization property of cocoa butter was directly related to these three TAG (MacMillan et al., 2002; Sato and Koyano, 2001).

In cocoa butter, the polymorphic variabilities are quite diverse. The confectionery industry uses Roman numerals as described by Willie and Lutton (1966) in which the six forms are given the names from Form I to Form VI. The forms have different melting points reported in the literature and the conversion from Form I to Form VI increases the stability and melting point of polymorphs (Rogers et al, 2008). The convention defined by Vaeck (1960) is more generally used in the oils and fat industry. This uses the Greek letters $\left(\gamma, \alpha, \beta^{\prime}\right.$ and $\left.\beta\right)$ to describe the main polymorphic forms.

Since cocoa buttercan crystallize into six different polymorphic forms, type and amount of different forms have a considerable effect on the quality of confectioneries and chocolates (MacMillan et al., 2002). Form $V$ is the most desirable form in chocolate products and formation of Form $\mathrm{VI}$ crystals is unwanted because it is often accompanied by the formation of fat bloom (Şekeroğlu, 2014; Sonwai and Rousseau, 2010; Afoakwa et al., 2009a; Afoakwa et al., 2009b). First of all, a bloomed chocolate is characterized by the loss of the surface's initial gloss. A bloomed chocolate can have different appearances, from a marble aspect to uniform dull gray, as well as from having small or large white spots on the chocolate surface (Şekeroğlu, 2014). Fat bloom is caused by many factors including compositions, improper processes and storage conditions (Altimiras et al., 2007; Lonchampt and Hartel, 2006; Sonwai and Rousseau, 2006). Tempering and cooling are the most important steps during chocolate production because controlling of polymorphism of cocoa butter is important for making chocolate with desired textural properties (Campos and Marangoni, 2014; Le Révérend, et al., 2009; Hartel, 2008; Koyano et al., 1990).

Many techniques such as pulsed Nuclear Magnetic Resonance (p-NMR), X-ray diffractometer (XRD), Polarized Light Microscopy (PLM) and Differential Scanning Calorimetry (DSC) can be used to study the crystallization behavior of fats (Şekeroğlu, 2014; Fessas et al., 2005; Marangoni, 2005; MacMillan et al., 2002; Spigno et al., 2001; Van Malssen, et al., 1999; Lipp and Anklam, 1998b; Metin and Hartel, 1998; Ziegleder, 1990). Also, effect of shear on the crystallization and polymorphic transformation of cocoa butter has been identified by using a rheometer (Şekeroğlu, 2014; Sonwai and Mackley, 2006; Toro-Vazquez et al., 2005; ToroVazquez et al., 2004; Ziegleder, 1985).

Although cooling and shear rates may affect polymorphism, formation of different polymorphs for a given lipid material depends mainly on the temperature at which the crystallization takes place. There are mainly three events in crystallization process: First is the solid phase formation which is called nucleation. The main driving force for nucleation is the difference between the chemical potential of a monomer in crystalline and supercooled liquid states (Mohos, 
2010). In other words, nucleation can be defined as the time point where the melt becomes visually cloudy and the temperature increases due to latent heat release (Campos and Marangoni, 2014).The second step is the crystallization or in another words crystal growth and the last one is crystal ripening (Toro-Vazquez et al., 2005). Several authors have investigated the effect of shear and cooling rate on crystallization of cocoa butter and chocolate (Campos and Marangoni, 2014; Fernandez et al., 2013; Mohos, 2010; Dhonsi and Stapley, 2006; Sonwai and Mackley, 2006; Toro-Vazquez et al., 2005; Brunello et al., 2003; Stapley et al., 1999). Many attempts have been made to control of crystallization of cocoa butter to achieve the crystallization in Form $\mathrm{V}$ which is the most desirable form (Sato and Koyano, 2001).

In this paper, the effect of shear and coolingheating rates on the crystallization and melting behavior of cocoa butter has been investigated at different temperatures. First, chemical and physical measurements were done to define the composition and properties of cocoa butter. Rheological analyses were done using a strain/stress controlled rheometer with a temperature controlled unit. The results from this paper will be useful to controlling of crystallization properties of cocoa butter in confectionery and chocolate production.

\section{Materials and Methods}

\section{Materials}

Cocoa butter was kindly supplied from a local firm in Gaziantep, Turkey. Chromatographic grade and other chemicals were purchased from Sigma Aldrich (St. Louis, MO, USA).

\section{Methods}

\section{Physical and chemical analysis}

Free fatty acid content, refractive index, saponification value, iodine value and color value of cocoa butter were done by the directive of Association of Official Analytical Chemists (AOAC, 1995).

\section{Triglyceride analysis}

Triacylglycerol composition of cocoa butter was analyzed using an High Performance Liquid chromatography (HPLC) instrument. It consists of Agilent 1200 series model quadratic pump, temperature controlled automatic injection unit, column heater and refractive index detector (Waldbronn, Germany). The Agilent Chemstation Rev. B.04.01 (Waldbronn, Germany) software program was used to monitor the device and analyze the peaks. Waters Spherisorb S5ODS2 (250 x $4.6 \mathrm{~mm})$ (Berkshire, England) column was used for TAG analysis. Mobile phase was a mixture of acetonitrile / acetone $(34.6 ; 65.4)$ (v:v). A calibration curve was prepared by using HPLC for determining TAG composition. Samples (5ml) were dissolved in acetone $(100 \mathrm{ml})$, and filtered using $0.45 \mu \mathrm{m}$ filters (Econofilters, Agilent Technologies, Waldbronn, Germany). Injection volume was $10 \mu \mathrm{l}$. Flow rate was $1.0 \mathrm{ml}$. $\mathrm{min}^{-1}$.

\section{Solid fat content analysis}

Minispec mq-20 model p-NMR (Bruker, Germany) was used to determine the solid fat content (SFC) of cocoa butter, according to AOCS Method Cd 16-81 (1989) (AOCS, 1989). Approximately 3 grams of cocoa butter were placed in glass NMR tubes ( $1 \mathrm{~mm}$ thickness, 180 $\mathrm{mm}$ height and $10 \mathrm{~mm}$ diameter) and melted at $80^{\circ} \mathrm{C}$ for 30 minutes and ensured that all the cocoa butter of crystallization has been removed. After the samples were prepared and tempered, a serial temperature profile was applied. Then samples were transferred to water baths set at 0 , $5,10,15,20,25,30,35$ and $40^{\circ} \mathrm{C}$. SFC readings were obtained after 60 minutes of isothermal static crystallization in a water bath. At least three sample tubes were measured at each temperature.

\section{Rheological measurements}

The rheological measurements were performed using a strain/stress controlled rheometer (Mars II-Haake $\mathrm{GmbH}$, Karlshure, Germany) with TCP/P peltier temperature controlled system. It was equipped with a cone- 
plate configuration using a cone radius of $35 \mathrm{~mm}$ and an angle of $1^{\circ}$ and a gap of $0.052 \mathrm{~mm}$ between the cone and the plate. Each measurement was replicated three times on the same sample.

The experimental parameters were chosen based on industrial chocolate tempering and cooling processes, types and properties of cocoa butter polymorphs and storage conditions. Two different cooling-heating rate values were applied to understand the effect of rapid and slow cooling/heating processes during industrial chocolate manufacture. In this context, rheological measurements were done after holding of cocoa butter at $70^{\circ} \mathrm{C}$ for $10 \mathrm{~min}$ to delete the crystal memory of cocoa butter. Then, sample was cooled from $70^{\circ} \mathrm{C}$ to $45^{\circ} \mathrm{C}$ with a 15 ${ }^{\circ} \mathrm{C} . \mathrm{min}^{-1}$ cooling rate. Crystallization was performed by cooling of cocoa butter from $45^{\circ} \mathrm{C}$ to critical temperatures $\left(20,22\right.$ and $\left.24^{\circ} \mathrm{C}\right)$ at the rates of cooling of 1 and $10^{\circ} \mathrm{C} \cdot \mathrm{min}^{-1}$ with different shear rates $\left(25,50\right.$ and $\left.100 \mathrm{~s}^{-1}\right)$ and then viscosity change was measured. Viscosity change of cocoa butter during heating and cooling processes between $70-20-70^{\circ} \mathrm{C}$ was measured again after holding of cocoa butter $10 \mathrm{~min}$ at $70^{\circ} \mathrm{C}$. These measurements were repeated for 1,5 and 10 ${ }^{\circ} \mathrm{C}$. $\mathrm{min}^{-1}$ cooling rates and 25,50 and $100 \mathrm{~s}^{-1}$ shear rates.

The equation which was the viscosity versus temperature function of (crystal free) cocoa butter was obtained from using Arrhenius equation from the temperature region between 30-70 $\mathrm{C}$.

Arrhenius equation can be denoted as (ToroVazquez et al., 2001),

$$
\eta=A \exp \left[\frac{E_{a}}{R T}\right]
$$

Here $\eta$ is the viscosity in Pa.s, $T$ is the absolute temperature in Kelvin, $E_{a}$ is the activation energy, $A$ is the pre-exponential factor and $R$ is the Universal gas constant.

\section{Statistical analysis}

Analysis of variance was performed by the Statgraphics version plus 5.1 (Statistical Graphics Corp.). Duncan's multiple range test was used to obtain comparisons among sample means. Evaluations were based on a $5 \%$ significance level $(P<0.05)$. All experiments and measurements were done in triplicate.

\section{Results and Discussion}

\section{Physical and chemical properties of cocoa butter}

Table 1 shows physical and chemical properties of cocoa butter used in this study. The chemical composition of cocoa butter was similar to other cocoa butters in literature and used in manufacturing of chocolate (Beckett, 2006; VanLangevelde et al., 2001; Lipp and Anklam, 1998a).

Table 1. Physical and chemical properties of cocoa butter ${ }^{1}$

\begin{tabular}{ll}
\hline Properties & Value \\
\hline Saponification Value (mg KOH/g fat) & $188 \pm 1.03$ \\
lodine Value (Wijs) & $25.81 \pm 0.57$ \\
Free Fatty Acid $(\%$ weight, as oleic acid) & $1.73 \pm 0.02$ \\
Refractive Index Value $\left(40^{\circ} \mathrm{C}\right)$ & $1.467 \pm 0.008$ \\
Color Value: & \\
YI (Yellowness Index) & $58.68 \pm 0.32$ \\
$\mathrm{~L}^{*}$ & $76.75 \pm 0.10$ \\
$\mathrm{a}^{*}$ & $-3.19 \pm 0.08$ \\
$\mathrm{~b}^{*}$ & $37.08 \pm 0.14$ \\
\hline${ }^{1}$ Values are based on triplicate analysis (Mean $\left.\pm \mathrm{SD}\right)$
\end{tabular}

${ }^{1}$ Values are based on triplicate analysis (Mean \pm SD)

\section{Solid fat content}

Figure 1 shows changes in SFC of cocoa butter found by NMR. Melting profile of cocoa butter was obtained by plotting the SFC as a function of temperature. The similar results for cocoa butter were found in literature (Perez-Martinez et al., 2007; Hartel, 2001). SFC value decreased when the temperature was increased, and complete melting of cocoa butter occurred between 35 and $40^{\circ} \mathrm{C}$. This melting profile has a great importance to evaluate the suitability of cocoa butter for chocolate and confectionery products (Afoakwa et al., 2007; Beckett, 2006; Schenk and Peschar, 2004). SFC values mostly depend on the composition and origin of cocoa butter The determination of SFC values at various temperatures is very useful when creating 
product physical attributes and predicting final product behavior (Torbica et al., 2005). For example, the physical properties of chocolate are affected by the SFC values of cocoa butter. Also, the result shows how the temperature affects the change in the SFC values and textural properties of chocolate.

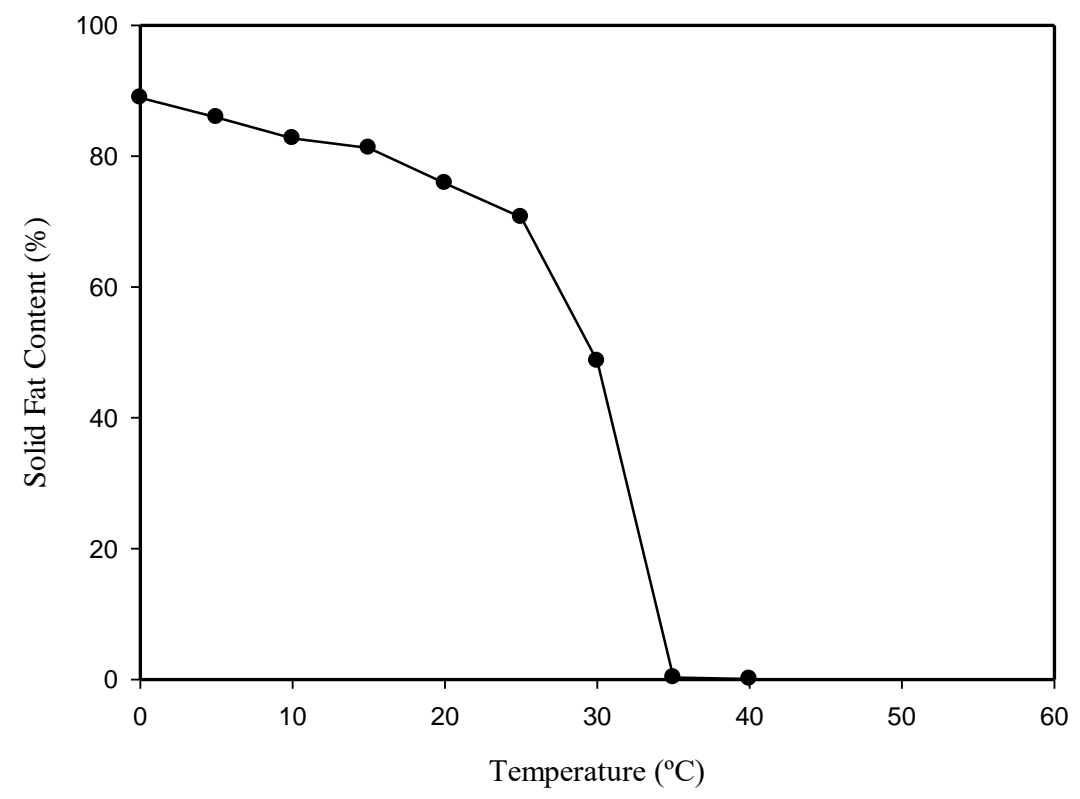

Figure 1. Solid fat content of cocoa butter obtained by NMR measurements

\section{TAG composition}

TAG composition for cocoa butter was calculated as \% area by using HPLC and found as POP: $19.09 \pm 0.08$, SOS: $32.71 \pm 0.57$ and POS: 48.19 \pm 0.63 . Natural cocoa butter contains $0.35 \%$ phospholipids, $1.71 \%$ mono and di-glycerides and 97-98\% triglyceride. Total amount of triglycerides, SOS (stearic-oleic-stearic), POS (palmitic-oleicstearic) and POP (palmitic-oleic-palmitic) were $85 \%$ in cocoa butter, so they were the most important ones and properties of cocoa butter were directly related to these three TAG (Fessas et al., 2005; Toro-Vazquez et al., 2004; Lipp and Anklam, 1998a; Loisel, et al., 1998). Dimick and Manning (1987) observed that the first visible crystals of cocoa butter contain POP, POS and SOS under static crystallization at 26 and $32^{\circ} \mathrm{C}$. Foubert et al. (2006) found that the composition of cocoa butter is important during isothermal crystallization of cocoa butter and differences in the chemical composition of fat phases cause differences in the crystallization kinetics.

\section{Rheological analysis}

Flow curve of cocoa butter was obtained and viscosity of cocoa butter was calculated from the slope of this curve at each temperature. Finally, viscosity change with temperature was presented in Table 2.

Table 2. Viscosity change of cocoa butter with temperature ${ }^{1}$

\begin{tabular}{ll}
\hline Temperature $\left({ }^{\circ} \mathrm{C}\right)$ & Viscosity (Pa.s) \\
\hline 70 & $0.0124 \pm 0.0002$ \\
60 & $0.0190 \pm 0.0002$ \\
50 & $0.0262 \pm 0.0003$ \\
40 & $0.0377 \pm 0.0004$ \\
30 & $0.0571 \pm 0.0006$ \\
\hline
\end{tabular}

${ }^{1}($ Mean \pm SD)

The Equation 2 which was the viscosity versus temperature function of (crystal free) cocoa butter was obtained from using the Equation 1 from the temperature region between $30-70^{\circ} \mathrm{C}$,

$\eta=1.838 \times 10^{-7} \exp \left[\frac{3833}{T}\right]$

Viscosity results of cocoa butter are similar and in a good agreement with the results reported by Landfeld et al. (2000). It is obviously stated that 
the progress of crystallization from the melt is controlled mainly by the removal of heat of crystallization. Viscosity determines the induction period and nucleation which consists of combination effect of cooling rate and super cooling (Toro-Vazquez et al., 2001).

The change in viscosity as a function of temperature, shear, heating and cooling rates between $70-20^{\circ} \mathrm{C}$ (cooling) and $20-70^{\circ} \mathrm{C}$ (heating) are presented in Figure 2. It was clearly seen that, the viscosity change was lower when the cooling rate was higher. When the cooling rate was 1 ${ }^{\circ} \mathrm{C} . \mathrm{min}^{-1}$, viscosity reached the highest value of 0.6 Pa.s with a shear rate of $25 \mathrm{~s}^{-1}$. Viscosity started to increase below $30^{\circ} \mathrm{C}$ with the order of rate as $10>5>1{ }^{\circ} \mathrm{C}$. $\mathrm{min}^{-1}$, viscosity increased rapidly below $22^{\circ} \mathrm{C}$ at $1{ }^{\circ} \mathrm{C} \cdot \mathrm{min}^{-1}$ rate. The viscosity of cocoa butter increased towards end of cooling step (around $20^{\circ} \mathrm{C}$ ) then the viscosity continued to increase at the beginning of heating cycle to a certain temperature then it tended to decrease and approached to melting viscosity value approximately at $30^{\circ} \mathrm{C}$. This behavior of cocoa butter was observed under all rates studied in this study.
The fall in viscosity occurred rapidly during heating cycle because of low heating rate (Figure 2a), but when the heating rate was increased, viscosity proceeded to increase and it followed a transition temperature at which rate of crystallization and melting were in equilibrium, and viscosity value remained nearly constant for a short time, then it decreased due to heating effect (Figure 2c).

Viscosity values of cocoa butter were always found higher at $25 \mathrm{~s}^{-1}$ shear rates on both melting and crystallization rheograms. As a result, shear was important to occurring of crystals or polymorphic transformation but after a certain limit, it has a melting effect acting like a thinning agent and occurring crystals are deforming under the high shear. Another interesting result was the change in viscosity while increasing temperature during the initial stage of the heating cycle. It can be explained that, after nucleation, crystals continue to grow after a certain time even though temperature increases.

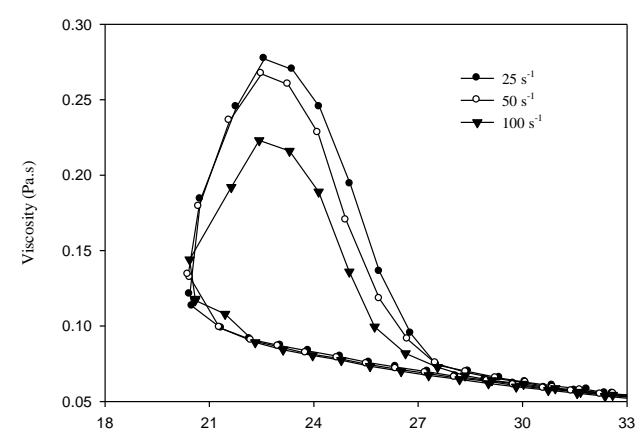

(b)

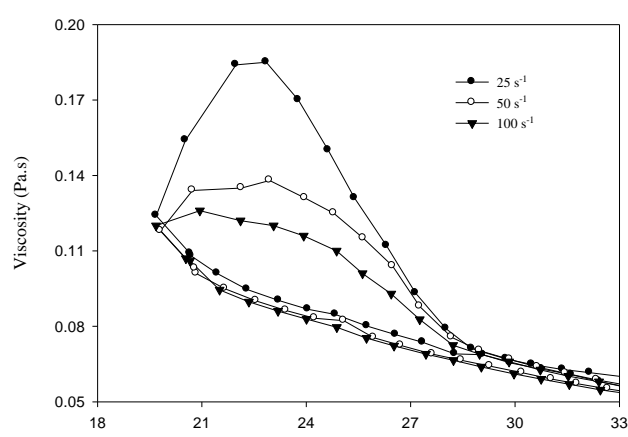

(c)

Figure 2. Effect of cooling - heating rates and shear rates on viscosity of cocoa butter (a) $1^{\circ} \mathrm{C} \cdot \mathrm{min}^{-1}$ (b) $5^{\circ} \mathrm{C} \cdot \mathrm{min}^{-1}$ (c) $10^{\circ} \mathrm{C}$. $\mathrm{min}^{-1}$ 
This result showed that temperature, shear and cooling rates influence the nucleation and crystal growth of cocoa butter. High shear rate has effect of breaking the solid fat crystals and uniformly distributing them. In addition, it provides heat and energy which increase the rate in which the more unstable crystals can change to more stable Form V (Beckett, 2006; Mazzanti et al., 2004). However, there is a major problem with high shear rates at which they can generate too much heat and results melting of all the crystals formed. Mostly cocoa butter is crystallized under shear in industrial chocolate and candies processes because mixing promotes heat transfer and helps to build a homogeneous product (Mazzanti et al., 2003).

The necessary shear rate and temperature during chocolate production can be achieved by using an instrument, tempermeter (Le Révérend, et al., 2009). The formation of true forms can be adjusted depending on the temper index value. Stapley et al. (1999) sheared the chocolate with a concentric cylinder and discovered that up to 27 $\mathrm{s}^{-1}$ shear rates, a peak crystallization temperature of $13^{\circ} \mathrm{C}$ was observed and this was the typical untempered chocolate. Campos and Marangoni (2014) studied the static and dynamic crystallization of cocoa butter and it was reported that the crystalline structure of cocoa butter cooled under the shear resulted in a high melting stable $\beta$ form. They also reported that the influence of high shear (400 rpm) on the crystallization of cocoa butter is more significant than any cooling rate effect. Also, MacMillan et al. (2002) demonstrated that temperature plays an important role in the formation of individual cocoa butter polymorphs. They also reported that forms III and IV were obtained under static conditions so shear was necessary to obtain the desired form $V$. The crystallization of chocolate under high shear has been investigated by Windhab et al. (1993) and with increasing shear stress, lower viscosities and significantly shorter solidification times were found by them.

The influence of shear (between $0-500 \mathrm{~s}^{-1}$ ) on the crystallization of $\mathrm{CB}$ was also investigated by
Sonwai and Mackley (2006) at a single temperature of $20^{\circ} \mathrm{C}$. They reported that shear influences crystallization kinetics and polymorphic structure of cocoa butter. It was also reported that at first, the viscosity increased slowly and much more rapidly at a later stage due to a second phase crystallization of fat phases under the influence of shear (Sonwai and Mackley, 2006).

The change in viscosity values of cocoa butter both during cooling and isothermal conditions was illustrated in Figure 3. Temperature plot was also added to rheograms because viscosity started to increase during cooling at low temperatures so this change was also important. The nucleation of crystals led to an increase in viscosity that occurred during the cooling stage. Similar behaviors had been observed in the crystallization of cocoa butter at $18.5^{\circ} \mathrm{C}$ and palm stearin/sesame oil blends at a cooling rate of 1 ${ }^{\circ} \mathrm{C}$. $\mathrm{min}^{-1}$ (Toro-Vazquez et al., 2004).

The effect of shear and cooling rates was more evident as the temperature decreased. (Figures $3 a$ and $3 b$ ). As expected the viscosity increased towards the end of the isothermal holding period and the increases in cooling and shear rates resulted in shorter induction periods. Dhonsi and Stapley (2006) and Toro-Vazques et al. (2004) also reported that an increase in the applied shear rate resulted a shorter induction time. The effect of shear was found to be more pronounced at low cooling rates. In the present study, the longest induction period was obtained at $24^{\circ} \mathrm{C}$.

There was an interesting situation during isothermal holding period at $20^{\circ} \mathrm{C}$. Viscosity increased rapidly as soon as isothermal step started, then the viscosity remained approximately constant at $1{ }^{\circ} \mathrm{C} \cdot \mathrm{min}^{-1}$ cooling rate because in this region, shear had an effect to melt unstable crystals formed during cooling and initial stage of isothermal period. Then transformation rate of unstable forms to stable ones increased with increasing shear rate as seen rapid change in viscosity at $100 \mathrm{~s}^{-1}$ (Figure 3a). However, a remarkably decrease in viscosity was seen at 10 ${ }^{\circ} \mathrm{C}$. $\mathrm{min}^{-1}$ cooling rate. So, after this intermediate 
region viscosity increased rapidly. This can be explained that small sized unstable crystals which

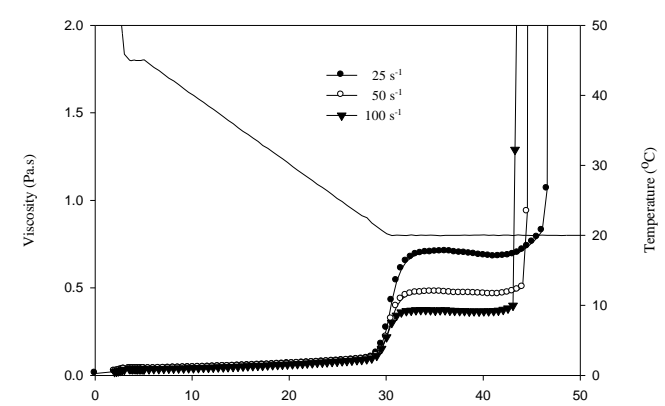

(a)

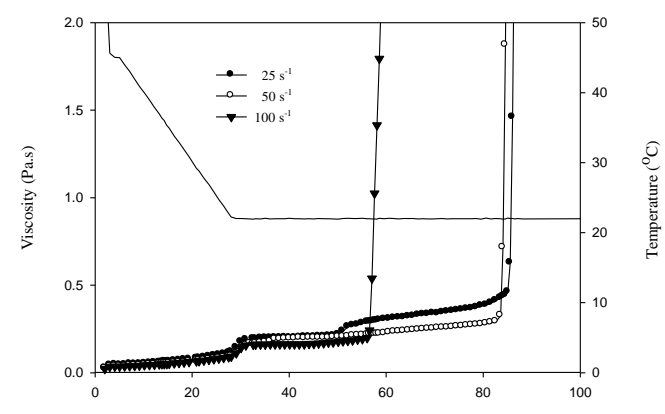

(c)

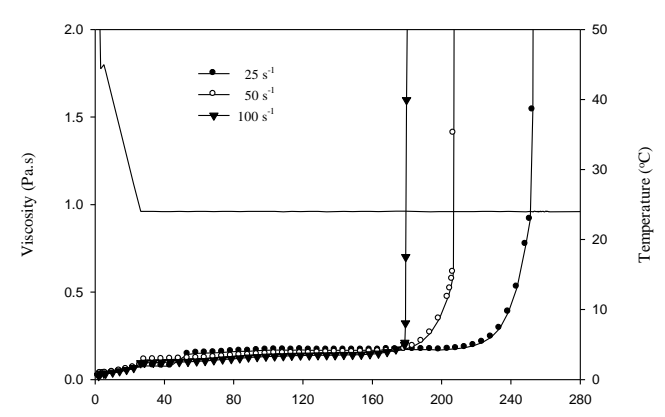

(e) formed during rapid cooling easily melted by the effect of shear.

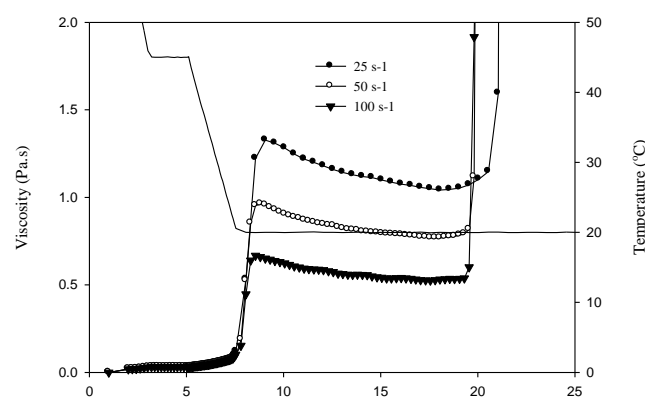

(b)

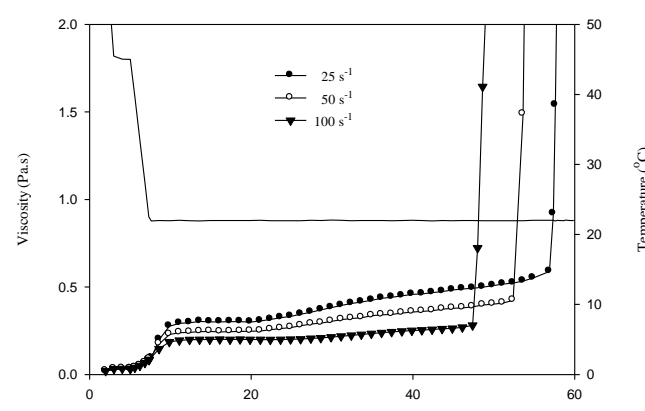

(d)

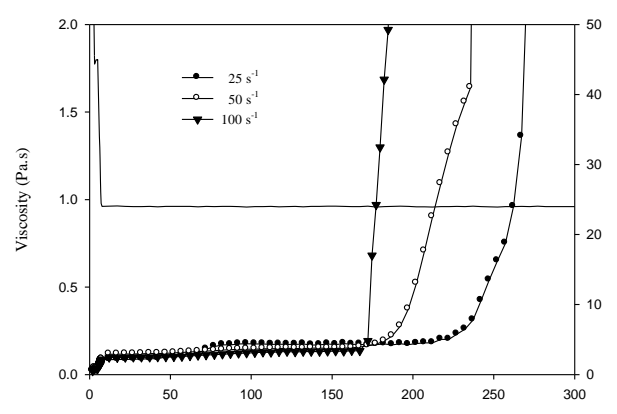

(f)

Figure 3. Change of viscosity of cocoa butter with temperature, shear and cooling rate (a) $1{ }^{\circ} \mathrm{C} \cdot \mathrm{min}^{-1}$ at $20^{\circ} \mathrm{C}$, (b) 10 ${ }^{\circ} \mathrm{C} \cdot \mathrm{min}^{-1}$ at $20^{\circ} \mathrm{C}$, (c) $1{ }^{\circ} \mathrm{C} \cdot \mathrm{min}^{-1}$ at $22^{\circ} \mathrm{C}$, (d) $10^{\circ} \mathrm{C} \cdot \mathrm{min}^{-1}$ at $22^{\circ} \mathrm{C}$, (e) $1{ }^{\circ} \mathrm{C} \cdot \mathrm{min}^{-1}$ at $24^{\circ} \mathrm{C}$ (f) $10^{\circ} \mathrm{C} \cdot \mathrm{min}^{-1}$ at $24^{\circ} \mathrm{C}$

Similar studies were done by Dhonsi and Stapley (2006) for cocoa butter and Loisel et al. (1998) for dark chocolate. They applied extremely low shear, $1 \mathrm{~s}^{-1}$ for cocoa butter. They observed crystallization in two steps or in other words, viscosity started to increase at the beginning and then an intermediate plateau region shown under this shear effect. They suggested that this twostep crystallization region may be arisen fractionation effect of fats. It was also known that, agitation of the seed crystals leads to secondary nucleation and it is an important phenomena especially in fractionation of fats (Hartel, 2001). It is observed clearly at low temperature and high shear rates in this study (Figure 3a, 3b). These results are consistent with literature findings where shear has been found to promote the formation of higher polymorphs. 
MacMillan et al. (2002) and Ziegleder (1985) sheared cocoa butter at $20^{\circ} \mathrm{C}$ and MacMillan et al. (2002) observed that Form IV was produced at $20^{\circ} \mathrm{C}$ without shear but formation of Form $\mathrm{V}$ was possible when a shear applied. Padar et al. (2009) investigated cocoa butter crystal formation and phase transition caused under the shear and they concluded that the initial form was $\alpha$ and the transformation into the Form $\mathrm{V}(\beta \mathrm{V})$ was confirmed up to $24^{\circ} \mathrm{C}$.

Furthermore, it has been known for a long time that shear induces the formation of Form $V$. Application of shear also helps the formation of Form V directly from Form III, bypassing Form IV. Another important effect of shear force is on the orientation of crystal lattice surfaces (or systems) that leads to phase transitions (Mazzanti et al., 2003). Ramel et al. (2018) studied on crystallization and form transition properties of different cocoa butter samples which were statically and dynamically cooled. They observed that transition into more stable forms (Form V) was found to be higher than dynamically cooled cocoa butter samples (Ramel et. al., 2018).

\section{Conclusions}

Cocoa butter is more complex phenomena and known six polymorphs are involved. The forming and transformation of phases are quite sophisticated. There are a lot of factors that affect the solidification and melting properties of cocoa butter. Some of them are composition of cocoa butter especially TAG's amount and process conditions. The results described here, both cooling and shear rates affect the crystallization behavior of cocoa butter. The rate of cooling was important. A rapid rate of cooling generally led to nucleation at a lower temperature than for slow cooling. Slower cooling rates generally led to nucleation at higher temperatures. Results showed that shear promoted Form $\mathrm{V}$ crystallization and induction times for crystallization reduced with an increase in shear rate. TAG have enough time to organize in the liquid state in lamellae structures while decreasing the temperature to achieve isothermal conditions and an increase in viscosity was observed with low cooling rate $\left(1{ }^{\circ} \mathrm{C} \cdot \mathrm{min}^{-1}\right)$. Effect of cooling rate was more significant at lower temperatures $(P<0.05)$. It was indicated that applying shear promotes a solid to a solid transformation of fats from unstable to more stable polymorphic forms.

Knowledge of the cooling and isothermal phase behavior of cocoa butter under different cooling and shear rates is important to optimize production processes and to maintain product quality. Chocolate's rheological properties are important in the manufacturing process to achieve high-quality products with a desired textural and sensory properties and cocoa butter is responsible for this as the main ingredient.

Tempering and cooling are the most critical steps in chocolate manufacture and these steps are strongly linked with fat migration and fat bloom of chocolate. Temperature and shear control are important correct crystallization of cocoa butter during tempering process. The degree of molecular packing of cocoa butter crystals network can be controlled using shear, resulting in improved cooling protocols in the processing of chocolate. The output of this study would be useful to understand the effects of cooling and shear rates on crystallization of cocoa butter which are the critical aspects that influenced the stability of chocolate products. It is also important for prevention of fat bloom of chocolate products.

\section{Acknowledgments}

This study was a "SANTEZ", an Industrial Project [00283.STZ.2008-1], which was supported by Republic of Turkey, Ministry of Science, Industry and Technology, and Şölen Chocolate, Food Industry and Trade, Gaziantep, Turkey.

Conflict of Interest: The authors declare that they have no conflict of interest.

Author Contributions : Gülten Şekeroğlu and 
Ahmet Kaya designed the study, evaluated the data and wrote the article and Gülten Şekeroğlu carried out the experiments. Both authors read and approved the final manuscript.

\section{References}

Afoakwa, E. O., Paterson, A., \& Fowler, M. (2007). Factors influencing rheological and textural qualities in chocolate. Trends in Food Science and Technology, 18, 290-298. DOI:http://dx.doi.org/10.1016/j.tifs. 2007.02.002

Afoakwa, E. O., Paterson, A., Fowler, M., \& Vieria, J. (2009a). Influence of tempering and fat crystallization behaviors on microstructural and melting properties in dark chocolate systems. Food Research International, 42, 200-209.

DOI:http://dx.doi.org/10.1016/j.foodres.2008.10.007

Afoakwa, E. O., Paterson, A., Fowler, M., \& Vieria, J. (2009b). Fat bloom development and structureappearance relationship during storage of undertempered dark chocolates. Journal of Food Engineering. 91, 571-581. DOI:http://dx.doi.org /10.1016/j.jfoodeng.2008.10.011

Altimiras, P., Pyle, L., \& Bouchon, P. (2007). Structure-fat migration relationship during storage of cocoa butter model bars: Bloom development and possible mechanisms. Journal of Food Engineering, 80, 600610.DOI:http://dx.doi.org10.1016/j.jfoodeng.2006.0 6.022

AOAC. Official Methods of Analysis of the Association of Official Analytical Chemists (AOAC). (1995). Association of Official Analytical Chemists, 16th edition. Arlington, VA, USA.

AOCS. American Oil Chemists' Society. (1989). Solid fat content (SFC) by low-resolution nuclear magnetic resonance- The indirect method. Cd 16-81.

Beckett, S.T. (2006). The Science of Chocolate, 2nd Edition, The Royal Society of Chemistry, Cambridge, United Kingdom, pp 85-103.

Beckett, S.T. (1999). Industrial Chocolate Manufacture and Use, 3rd Edition, Blackwell Science, Oxford, UK.

Brunello, N., McGauley, S. E., \& Marangoni, A. G. (2003). Mechanical properties of cocoa butter in relation to its crystallization behavior and microstructure. LWTFood Science and Technology. 36, 525-532.

DOI:https://doi.org/10.1016/S0023-6438(03)00053-7

Campos, R., \& Marangoni, A. G. (2014). Crystallization dynamics of shear worked cocoa Butter. Crystal Growth \& Design, 14(3), 1199-1210. https://doi.org/10.1021/cg4017273

Dhonsi, D., \& Stapley, A. G. F. (2006). The effect of shear rate, temperature, sugar and emulsifier on the tempering of cocoa butter. Journal of Food Engineering. 77, 936-942. DOI: https://doi.org/10.1016/j.jfoodeng.2005.08.022

Dimick, P. S., \& Manning, D. M. (1987). Thermal and compositional properties of cocoa butter during static crystallization. Journal of the American Oil Chemists Society. 64, 1663-1669. DOI: https://doi.org/10.1007/BF02542500
Fernandez, V. A., Müller, A. J., \& Sandoval, A. J. (2013). Thermal, structural and rheological characteristics of dark chocolate with different compositions. Journal of Food Engineering. 116, 97-108.

DOI: https://doi.org/10.1016/j.jfoodeng.2012.12.002

Fessas, D., Signorelli, M., \& Schiraldi, A. (2005). Polymorphous transitions in cocoa butter. A quantitative DSC study. Journal of Thermal Analysis and Calorimetry. 82, 691-702. DOI: https://doi.org/10.1007/s10973-005-0952-7

Foubert, I., Vanrolleghem, P. A., Thas, O., \& Dewettinck, K. (2006). Influence of chemical composition on the isothermal cocoa butter crystallization. Journal of Food Science, 69(9), E478-E487. https://doi.org/10.1111/j.1365-2621.2004.tb09933.x

Hartel R.W. (2008). The Crystalline State. In: Aguilera J.M., Lillford P.J. (eds) Food Materials Science. Springer, New York, NY. https://doi.org/10.1007/978-0-387-71947-4_4

Hartel, R. W. (2001). Crystallization in Foods. An Aspen Publication Gaithersburg, MD, USA, pp 34-87.

Koyano, T., Hachiya, I., \& Sato, K. (1990) "Fat polymorphism and crystal seeding effects on fat bloom stability of dark chocolate," Food Structure: Vol. 9 : No.3 , Article 6. Available at:https://digitalcommons.usu.edu/ foodmicrostructure /vol9/iss3/6

Landfeld, A., Novotna, P., Strohalm, J., Houska, M., \& Kyhos, K. (2000). Viscosity of cocoa butter. International Journal of Food Properties. 3, 165-169. DOI: https://doi.org/10.1080/10942910009524623

Le Révérend, B. J. D., Fryer, P. J., \& Bakalis, S. (2009). Modelling crystallization and melting kinetics of cocoa butter in chocolate and application to confectionery manufacturing. Soft Matter, 5(4), 891902.https://doi.org/10.1039/b809446b

Lipp, M., \& Anklam, E. (1998a). Review of cocoa butter and alternative fats for use in chocolate-Part $A$. Compositional data. Food Chemistry. 62, 73-97. DOI:https://doi.org/10.1016/S0308-8146(97)00160-X

Lipp, M., \& Anklam, E., (1998b). Review of cocoa butter and alternative fats for use in chocolate-Part B. Analytical approaches for identification and determination. Food Chemistry. 62, 99-108. DOI: https://doi.org/10.1016/S0308-8146(97)00161-1

Loisel, C., Keller, G., Lecq, G., Bourgaux, C., \& Ollivon, M. (1998). Phase transitions and polymorphism of cocoa butter. Journal of the American Oil Chemists Society. 75, 425-439. DOI: https://doi.org/10.1007/s11746998-0245-y

Lonchampt, P., \& Hartel, R. W. (2006). Surface bloom on improperly tempered chocolate. European Journal of Lipid Science and Technology. 108, 159-168. DOI: https://doi.org/10.1002/ejlt.200500260

MacMillan, S. D., Roberts, K. J., Rossi, A., Wells, M. A., Polgreen, M. C., \& Smith, I. H. (2002). In situ small angle X-ray scattering (SAXS) studies of polymorphism with the associated crystallization of cocoa butter fat using shearing conditions. Crystal Growth and Design. 2 (3), 221-226. DOI: https://doi.org/10.1021/cg0155649

Marangoni, A. G. (2005). Fat Crystal Network. Marcel Dekker, New York, USA, pp 21-83.

Mazzanti, G., Guthrie, S. E., Sirota, E. B., Marangoni, A. G., \& 
Idziak, S. H. J. (2004). Novel shear-induced phases in cocoa butter. Crystal Growth \& Design, 4(3), 409411. https://doi.org/10.1021/cg034260e

Mazzanti, G., Guthrie, S. E., Sirota, E. B., Marangoni, A. G., \& Idziak, S. H. J. (2003). Orientation and phase transitions of fat crystals under shear. Crystal Growth and Design. 3, 721-725. DOI: https://doi.org/10.1021/cg034048a

Metin, S., \& Hartel, R.W. (1998). Thermal analysis of isothermal crystallization kinetics in blends of cocoa butter with milk fat or milk fat fractions. Journal of the American Oil Chemists Society. 75, 1617-1624. DOI: https://doi.org/10.1007/s11746-998-0102-z

Mohos, F. (2010). Confectionery and Chocolate Engineering, Principles and Applications, 1st edition, John Wiley \& Sons, Ltd., Publication, West Sussex, UK.

Padar, S., Mehrle, Y. E., \& Windhab, E. J. (2009). Shearinduced crystal formation and transformation in cocoa butter. Crystal Growth \& Design, 9(9), 40234031. https://doi.org/10.1021/cg900194t

Perez-Martinez, D., Alvaros-Salas, C., Charo-Alonso, M., Dibildox-Alvarado, E., \& Toro-Vazquez, J. F. (2007). The cooling rate effect on the microstructure and rheological properties of blends of cocoa butter with vegetable oils. Food Research International. 40, 4762. DOI: https://doi.org/10.1016/j.foodres.2006.07.016

Ramel, P. R., Campos, R., \& Marangoni, A. G. (2018). Effects of Shear and Cooling Rate on the Crystallization Behavior and Structure of Cocoa Butter: Shear Applied During the Early Stages of Nucleation. Crystal Growth \& Design, 18(2), 1002-1011. https://doi.org/10.1021/acs.cgd.7b01472

Rogers M.A., Tang D., Ahmadi L., Marangoni A.G. (2008) Fat Crystal Networks. In: Aguilera J.M., Lillford P.J. (eds) Food Materials Science. Springer, New York, NY. https://doi.org/10.1007/978-0-387-719474_17

Sato, K., \& Koyano, T. (2001). Crystallization properties of cocoa butter in Crystallization Processes in Fats and Lipid Systems, ed by Garti, N. and Sato, K., Marcel Dekker Inc, New York, USA, pp 429-456.

Schenk, H., \& Peschar, R. (2004). Understanding the structure of chocolate. Radiation Physics and Chemistry. 71, 829-835. DOI: https://doi.org/10.1016/j.radphyschem.2004.04.105

Sonwai, S., \& Mackley, M. R. (2006). The effect of shear on the crystallization of cocoa butter. Journal of the American Oil Chemists Society. 83, 593-596. DOI: https://doi.org 10.1007/s11746-006-1243-6

Sonwai, S., \& Rousseau, D. (2006). Structure evolution and bloom formation in tempered cocoa butter during long term storage. European Journal of Lipid Science and Technology. 108, 735-745.

DOI: https://doi.org/10.1002/ejlt.200600078

Spigno, G., Pagella, C., \& De Faveri, D. M. (2001). DSC characterization of cocoa butter polymorphs. Italian Journal of Food Science. 13, 275-284.

Stapley, A. G. F., Tewkesbury, H., \& Fryer, P. J. (1999). The effects of shear and temperature history on the crystallization of chocolate. Journal of the American Oil Chemists Society. 76, 677-685. DOI: https://doi.org/10.1007/s11746-999-0159-3

Şekeroğlu, G. (2014). Investigation of fat bloom mechanism in dark chocolate. PhD Thesis. University of Gaziantep. Food Engineering Department.

Torbica, A., Jovanovic, O., \& Pajin, B. (2005). The advantages of solid fat content determination in cocoa butter and cocoa butter equivalents by the Karlshamns method. European Food Research and Technology, 222(3-4), 385-391. https://doi.org/10.1007/s00217-005-0118-7

Toro-Vazquez, J. F., Dibildox-Alvaradom, E., HerreraCoronado, V., \& Charo-Alonso, M. A. (2001). Triacylglyceride crystallization in vegetable oils: application of models, measurements, and limitations in Crystallization and Solidification Properties of Lipids ed by Widlak, N., Hartel, R. and Narine, S., AOCS Press, Champaign, USA, pp 53-78.

Toro-Vazquez, J. F., Perez-Martinez, D., Dibildox-Alvarado, E., Charo-Alonso, M., \& Reyes-Hernandez, J. (2004). Rheometry and polymorphism of cocoa butter during crystallization under static and stirring conditions. Journal of the American Oil Chemists Society. 81, 195-202.

DOI: https://doi.org/10.1007/s11746-004-0881-z

Toro-Vazquez, J. F., Rangel-Vargas, E., Dibildox-Alvarado, E., \& Charo-Alonso, M. A. (2005). Crystallization of cocoa butter with and without polar lipids evaluated by rheometry, calorimetry and polarized light microscopy. European Journal of Lipid Science and Technology. 107, 641-655. DOI: https://doi.org/10.1002/ejlt.200501163

Vaeck, S. V. (1960). Cocoa butter and fat bloom. The Manufacturing Confectioner. 40, 35-46 and 71-74.

Van Malssen, K., Van Langevelde, A., Peschar, R., \& Schenk, H. (1999). Phase behavior and extended phase scheme of static cocoa butter investigated with realtime X-ray powder diffraction. Journal of the American Oil Chemists Society. 76, 669-676. DOI: https://doi.org/10.1007/s11746-999-0158-4

Van-Langevelde, A., Van Malssen, K., Peschar, R., \& Schenk, H. (2001). Effect of temperature on recrystallization behavior of cocoa butter. Journal of the American Oil Chemists Society. 78, 919-925.

DOI: https://doi.org/10.1007/s11746-001-0364-2

Willie, R.L., \& Lutton, E. S. (1966). Polymorphism of cocoa butter. Journal of the American Oil Chemists Society. 43, 491-496.DOI:https://doi.org/10.1007/BF02641273

Windhab, E. J., Niediek, E. A. \& Rolfes, L. (1993). Tieftemperatur-scherkristallisationneue aspekte der temperiertechnik. Siisswaren, 3, 32-37.

Yıldırım, A., Çetin, S., Öğretmen, H., Sarı, P., \& Hayoğlu, ì. (2016). Narın çikolata üretiminde kullanimi. Harran Tarım ve Gıda Bilimleri Dergisi. 20(1), 12-19. DOI: 10.29050/harranziraat.194283

Ziegleder, G. (1985). Improved crystallization behavior of cocoa butter under shearing. Int Z Lebensm Techn Verfahrenst. 36, 412-418.

Ziegleder, G. (1990). DSC - Thermal analysis and kinetics of cocoa butter crystallization. Fat Science Technology. $92,481-485$. 